University of Montana

ScholarWorks at University of Montana

$12-2008$

\title{
The Ecological Importance of Severe Wildfires: Some Like it Hot
}

Richard L. Hutto

University of Montana - Missoula, hutto@mso.umt.edu

Follow this and additional works at: https://scholarworks.umt.edu/biosci_pubs

Part of the Biology Commons

Let us know how access to this document benefits you.

\section{Recommended Citation}

Hutto, Richard L., "The Ecological Importance of Severe Wildfires: Some Like it Hot" (2008). Biological Sciences Faculty Publications. 279.

https://scholarworks.umt.edu/biosci_pubs/279

This Article is brought to you for free and open access by the Biological Sciences at ScholarWorks at University of Montana. It has been accepted for inclusion in Biological Sciences Faculty Publications by an authorized administrator of ScholarWorks at University of Montana. For more information, please contact scholarworks@mso.umt.edu. 


\title{
Communications
}

Ecological Applications, 18(8), 2008, pp. 1827-1834

(C) 2008 by the Ecological Society of America

\section{THE ECOLOGICAL IMPORTANCE OF SEVERE WILDFIRES: SOME LIKE IT HOT}

\author{
RichARD L. HutTo ${ }^{1}$ \\ Avian Science Center, Division of Biological Sciences, University of Montana, Missoula, Montana 59812 USA
}

\begin{abstract}
Many scientists and forest land managers concur that past fire suppression, grazing, and timber harvesting practices have created unnatural and unhealthy conditions in the dry, ponderosa pine forests of the western United States. Specifically, such forests are said to carry higher fuel loads and experience fires that are more severe than those that occurred historically. It remains unclear, however, how far these generalizations can be extrapolated in time and space, and how well they apply to the more mesic ponderosa pine systems and to other forest systems within the western United States. I use data on the pattern of distribution of one bird species (Black-backed Woodpecker, Picoides arcticus) as derived from 16465 sample locations to show that, in western Montana, this bird species is extremely specialized on severely burned forests. Such specialization has profound implications because it suggests that the severe fires we see burning in many forests in the Intermountain West are not entirely "unnatural" or "unhealthy." Instead, severely burned forest conditions have probably occurred naturally across a broad range of forest types for millennia. These findings highlight the fact that severe fire provides an important ecological backdrop for fire specialists like the Black-backed Woodpecker, and that the presence and importance of severe fire may be much broader than commonly appreciated.
\end{abstract}

Key words: Black-backed Woodpecker; fire history; fire regime; mixed-conifer forest; Picoides arcticus; severe fire.

\section{INTRODUCTION}

Dry, ponderosa pine-dominated forests of the western United States are widely believed to have experienced a buildup of fuels in the past century due to a combination of over-aggressive fire suppression efforts, overgrazing, and overharvesting (Covington and Moore 1994, Allen et al. 2002, Arno and Allison-Bunnell 2002, Arno and Fiedler 2005). As a result, those western forests are now said to suffer from more extreme fire behavior (Donovan and Brown 2007) or to burn with unnatural or unprecedented intensity. Indeed, severe fires are routinely referred to as "catastrophic" events in the popular press, and such terminology appears even in proposed congressional legislation drafted to deal with severe fire's aftermath (e.g., HR4200). Given the prevailing view, and the current rate at which land managers are implementing forest restoration projects specifically designed to prevent severe fire within and, more importantly, beyond the dry, ponderosa pine system,

Manuscript received 13 May 2008; accepted 20 June 2008. Corresponding Editor: R. L. Knight.

${ }^{1}$ E-mail: hutto@mso.umt.edu one would hope that generalizations about the state of our forests are broadly applicable. Unfortunately, we may be inappropriately extrapolating results from the ponderosa pine system to the more mesic ponderosa pine systems and to other forest types (Shinneman and Baker 1997, Johnson et al. 2001, Schoennagel et al. 2004, Baker et al. 2007), which make up the vast majority (about $85 \%$ ) of forested area in the West (data available online). ${ }^{2}$

The ecology and life history adaptations of living organisms are still underused as sources of reliable information in the debate about what constitutes "natural" forest conditions and fire regimes in any forest type. This is surprising, given that the goal of forest restoration is to return forests to conditions that reflect their evolutionary past (Covington 2000). Through their precise selection of suitable habitat, organisms carry an abundance of historical information about the environments within which they evolved. Moreover, that evolutionary history is valuable because it runs much deeper than the 100- to 500-year reach of

\footnotetext{
${ }^{2}\langle$ http://www.landfire.gov/ $\rangle$
} 
most historical (e.g., fire-scarred tree-ring) studies. If restoration forestry is to become as common and as broadly applied as current trends suggest, then the ecological setting within which organisms evolved should receive considerable weight in the formulation of restoration goals. For example, consider the question of whether forests outside the dry ponderosa pine system are really in need of "restoration." While stem densities and fuel loads may be much greater today than a century ago, those patterns are perhaps as much a reflection of human activity in the recent past (e.g., timber harvesting) as they are a reflection of historical conditions (Shinneman and Baker 1997). Without embracing an evolutionary perspective, we run the risk of creating restoration targets that do not mimic evolutionarily meaningful historical conditions, and that bear little resemblance to the conditions needed to maintain populations of native species, as mandated by law (e.g., National Forest Management Act of 1976).

The identification of species that specialize on burned forests might be particularly useful in the debate about what kind of fire regime falls within the historical range of natural variation for a given forest type. Species that are extreme specialists in habitat use are necessarily key indicators of specific environmental conditions that must have occurred naturally in the past. If the fires of today are actually unnatural or unprecedented, the only organisms able to use either the unnaturally dense, green forests or the postfire forest conditions created by unnaturally severe fires would be those opportunistic species that are broadly distributed and able to occupy both naturally created and unnaturally created conditions. Extreme specialization by an organism can evolve only if the particular conditions to which it is adapted were sufficiently abundant during its speciation, which for most bird species occurred millions of years ago (Barker et al. 2004). Thus, a species cannot be restricted in its distribution to those forest conditions that we deem to be unnatural because the evolutionary window of time needed to shift from the environmental condition within which it evolved to something entirely different is probably much longer than the half-century time window during which forest conditions have supposedly become unnaturally dense. Any forest condition occupied to the exclusion of other forest types or conditions would have to be considered natural, and would necessarily lie within the historical range of natural variation.

The Black-backed Woodpecker is generally assumed to be strongly associated with burned forest conditions (Dixon and Saab 2000). However, the only comparative data bearing on that assumption (Hutto 1995) were derived from a literature-based meta-analysis of studies that differed in duration and survey methodology and that were conducted across a relatively small number of vegetation types. Now, 13 years later, the U.S. Forest Service Northern Region Landbird Monitoring Program (Hutto and Young 2002) has amassed one of the largest bird point-count databases of its kind, with sample locations drawn from a wide range of unburned vegetation types across northern Idaho and western Montana. By combining those data with data collected from additional locations distributed across more than 50 fires that had burned in western Montana during the past 20 years, I was able to ask whether the Blackbacked Woodpecker is relatively restricted to burned forest conditions and, if so, which particular kind of burned forest conditions it tends to occupy.

\section{Methods}

To show that an organism is restricted in its distribution to a narrow set of conditions, one must have reliable information on its occurrence across a wide (ideally, a complete) range of existing conditions. Data for this analysis were drawn from a pool of 48155 point counts that have been conducted within 20 different vegetation types throughout northern Idaho and Montana since inception of the U.S. Forest Service Northern Region Landbird Monitoring Program (Hutto and Young 2002) in 1994 (Fig. 1). Points were at least 250 $\mathrm{m}$ from any other point and most were distributed along 10-point transects that were themselves distributed in a geographically stratified manner across the region. More specifically, start points were located on the nearest dirt road or trail to a randomly selected point in all $7.5-\mathrm{min}$ USGS topographic quad map quarter-sections that included U.S. Forest Service lands. I considered only single visits to a given point by using data from the first year that a point was visited, which resulted in 13337 independent sample points. Samples within postfire vegetation were collected from an additional 3128 points that were distributed broadly among 50 different recently burned (1-4 years postfire) forests as part of research efforts that were independent of the land bird monitoring program (Fig. 1). Points within burn perimeters were also $250 \mathrm{~m}$ apart and were either located on straight-line transects that were randomly oriented from a near-road start point (prior to 2003) or (after 2003) were part of a grid-based sampling design where points were randomly placed on a GIS layer within 225-ha grids positioned to capture a broad range of fire severities. The grid-based points were uploaded onto GPS units prior to the field season and field technicians walked to the designated points to conduct bird surveys.

Bird surveys were conducted using a standard 10-min point-count protocol (Ralph et al. 1995), with presence/absence as the response variable. Observers working within and near sites that were burned in 2003 also played back recordings of Black-backed Woodpecker drums and calls through FoxPro broadcast callers (FoxPro, Lewistown, Pennsylvania, USA) during 5min test periods. Playbacks were conducted either immediately following formal point counts (about 2500 times) or on roads and trails in and around burned forests where formal point counts were not conducted 


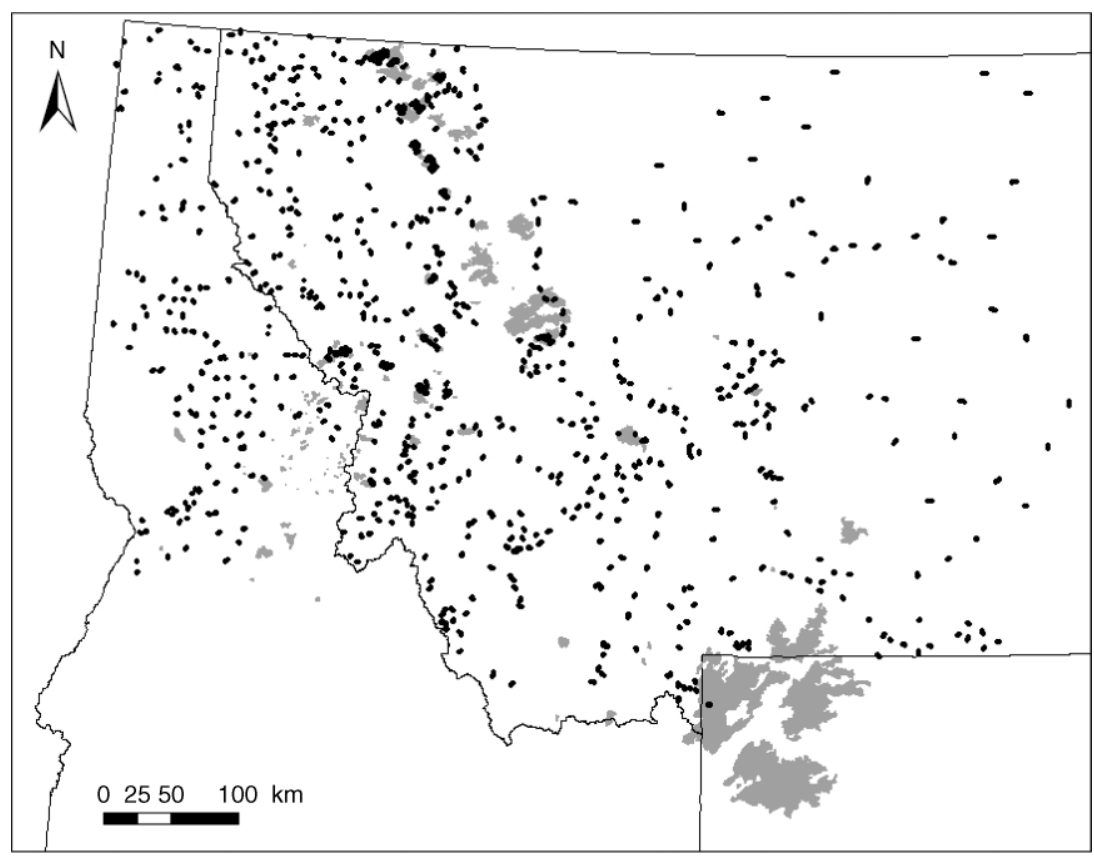

FIG. 1. Locations of U.S. Forest Service Northern Region land bird monitoring points and the more recent (after 2003) fire research points used for determining the pattern of Black-backed Woodpecker occurrence across vegetation types in northern Idaho and western Montana, USA. Also shown (in gray) are the 1988-2003 fires that were visited to obtain bird occurrence data within burned forests.

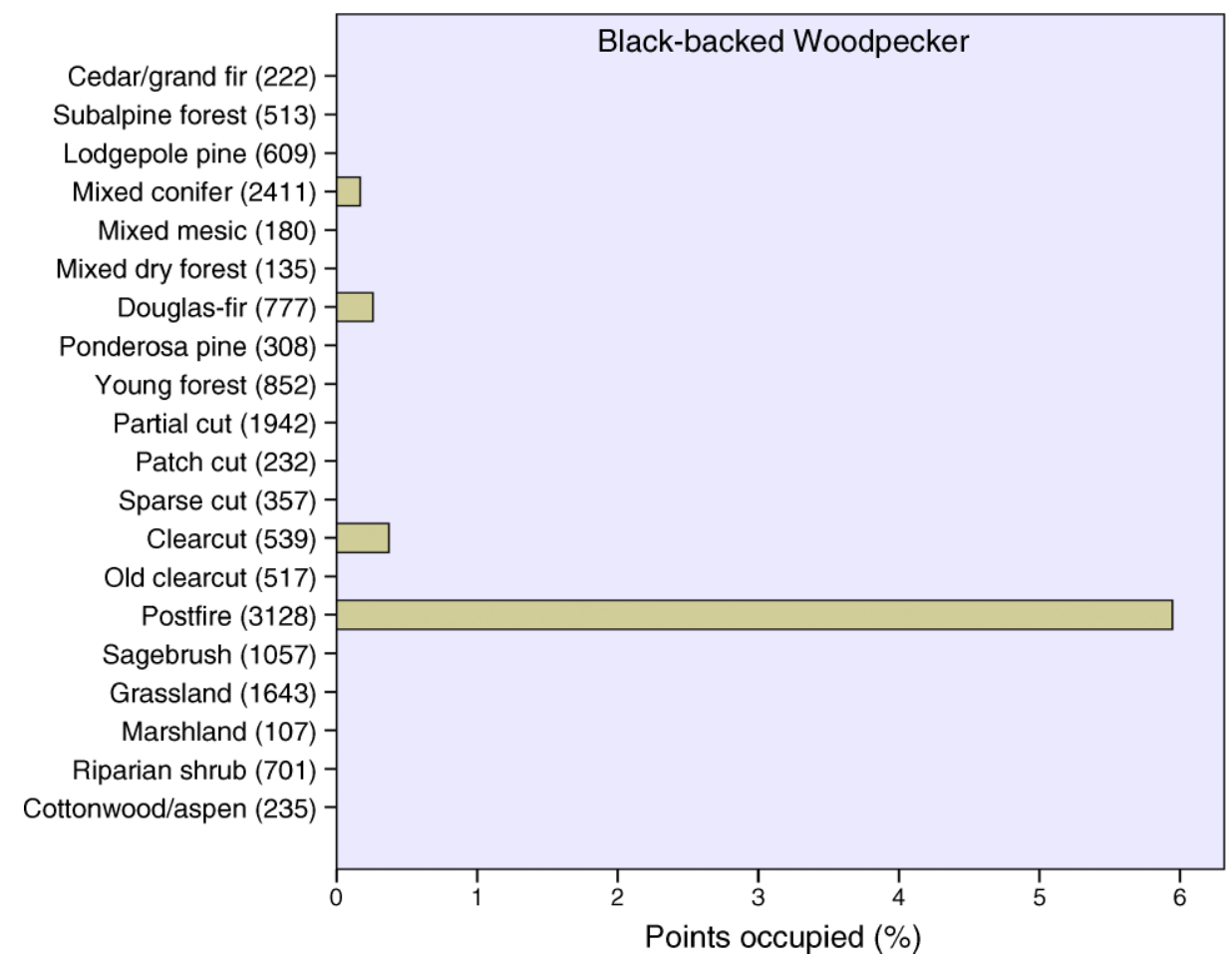

FIG. 2. Histogram bars indicate the percentage of points (sample sizes in parentheses) at which the Black-backed Woodpecker was detected in each of 20 distinct vegetation types within northern Idaho and western Montana. The distribution is nonrandom $\left(\chi^{2}=559.43, \mathrm{df}=19, P<0.0001\right)$ and reveals that the Black-backed Woodpecker is highly specialized in its use of burned conifer forest. 

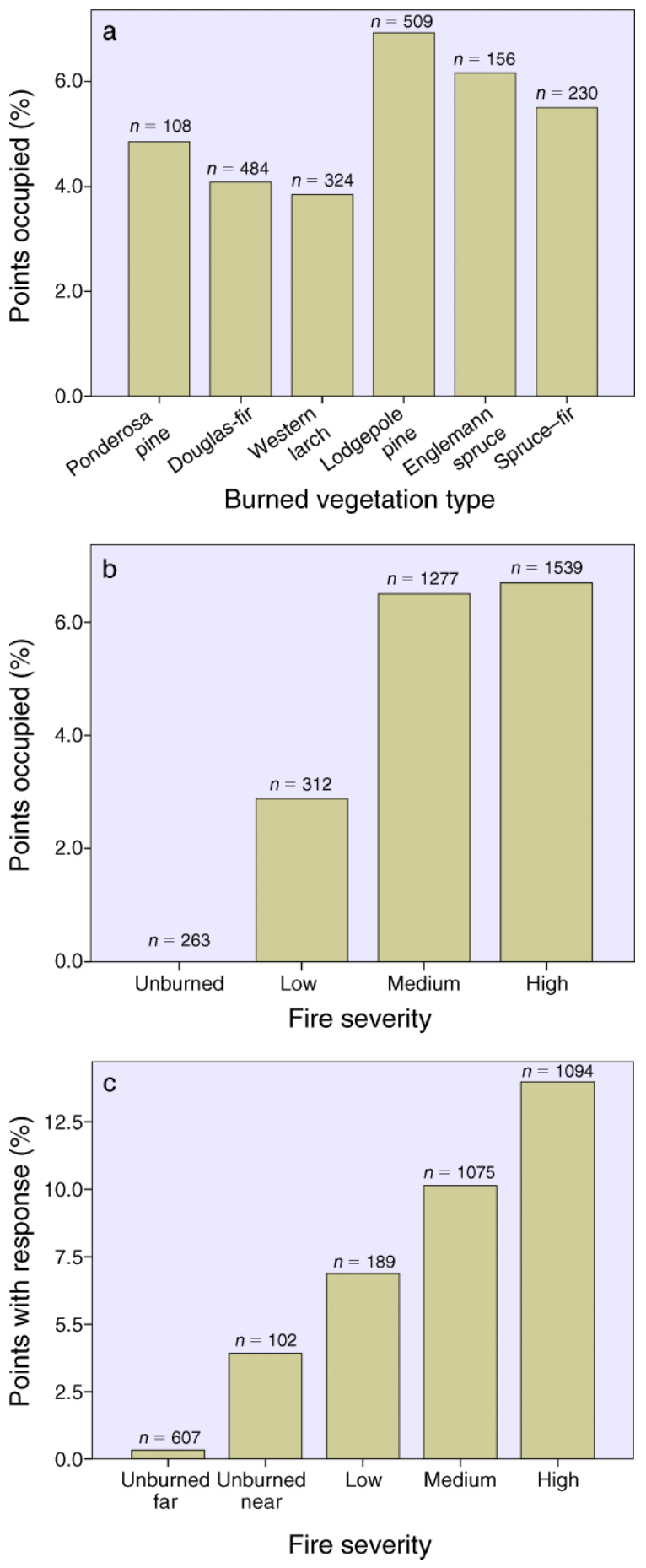

FIG. 3. (a) The probability of detecting a Black-backed Woodpecker in burned forest does not differ $\left(\chi^{2}=3.99\right.$, $\mathrm{df}=5$, $P=0.55$ ) among forest types. (b) The probability of detecting a Black-backed Woodpecker increases $\left(\chi^{2}=36.07, \mathrm{df}=3, P<\right.$ 0.0001 ) with fire severity, as defined in the methods section. (c) The probability of detecting a Black-backed Woodpecker in response to experimental playbacks of territorial drumming increased $\left(\chi^{2}=132.40, \mathrm{df}=4, P<0.0001\right)$ with fire severity. Playbacks in the "unburned-far" forests were conducted in green-tree forests beyond the fire perimeter of recently burned areas, whereas playbacks in the "unburned-near" forests were
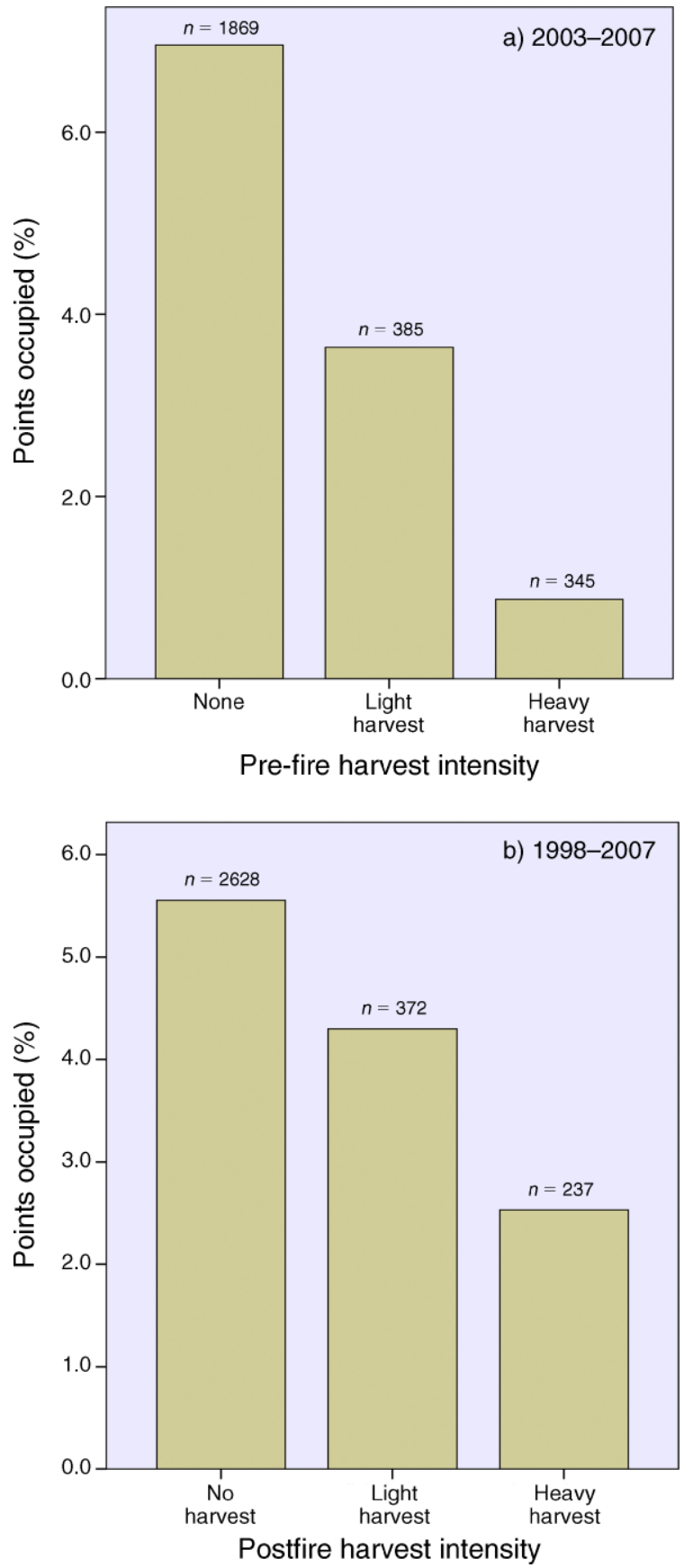

FIG. 4. The probability of detecting a Black-backed Woodpecker decreases incrementally with intensity (see Meth$o d s)$ of both (a) recent pre-fire $\left(\chi^{2}=31.5, \mathrm{df}=2, P<0.0001\right)$ and (b) recent postfire $\left(\chi^{2}=5.49, \mathrm{df}=2, P=0.06\right)$ timber harvesting.

conducted in green-tree patches within burned-forest fire perimeters. Sample sizes (number of survey points visited) are given above bars. 
(about 500 times). Playback call locations were generally spaced at least $500 \mathrm{~m}$ apart and included the full range of fire severities, from unburned to severely burned sites. A 25-s recording of drumming and calls was played, after which the observer listened for $2 \mathrm{~min}$ for a response before employing a second 2.5-min playback and listening period. Either the presence or absence of a definitive vocal or visual response by a Black-backed Woodpecker was noted.

The dominant vegetation type within $100 \mathrm{~m}$ of a survey point fell into one of 20 distinct categories (see Fig. 2), as defined by a combination of dominant canopy plant species and age after stand initiation (more formal definitions provided in Hutto and Young [1999]). The postfire vegetation type was subdivided more finely into six categories based on the nominal tree species that provided more than $60 \%$ of the canopy cover within 30 $\mathrm{m}$ of the survey point. Fire severity was determined from a ground-based assessment of the proportion of trees that were green-needled, brown-needled, and blackened within $50 \mathrm{~m}$ of the survey point as follows: $100 \%$ green (unburned), 80-99\% green (low-severity), $<80 \%$ green and $<80$ blackened (medium severity), and $>80 \%$ blackened (high severity). These four categories correspond well with the four categories derived from the normalized burn ratio used by the USDA Forest Service to produce burned area reflectance classifications for national-level support of Burned Area Emergency Rehabilitation activities (Lutes et al. 2006, Schwind 2008). Observers recorded evidence of recent pre-fire timber harvest activity within the past decade or two surrounding (to a distance of at least $100 \mathrm{~m}$ from) each survey point that was visited between 2003 and 2007. The timber harvest activity was subjectively categorized into one of three categories: "none" (no evidence based on the presence of recent tree stumps), "light harvest" (evidence of levels of tree removal associated with minor selective harvesting through moderate shelter wood cutting), or "heavy harvest" (evidence of extensive tree removal associated with a seed-tree cut or clearcut). The same categories were used to classify levels of postfire timber harvesting surrounding survey locations visited between 1988 and 2007.

The resulting numbers of independent points used to determine the probability of detection within any one vegetation, severity, or harvest category was at least 100 . I used the Likelihood-ratio chi-square test (Sokal and Rohlf 1995) to determine whether frequencies of detection differed significantly among vegetation, severity, and harvest categories, and I calculated standardized selection ratios (Manly et al. 2002) to illustrate preference for one vegetation type over another.

\section{RESUlTS}

The Black-backed Woodpecker is clearly an extreme habitat specialist that is relatively restricted $\left(\chi^{2}=559.43\right.$, df $=19, P<0.0001$ ) to burned forest conditions (Fig. 2). No other bird that occupies conifer forests is as specialized on such a small a subset of forest types or conditions (compare with other bird species distribution patterns in Hutto and Young [1999]). Based on standardized selection ratios (Manly et al. 2002), the Black-backed Woodpecker is 16 times more likely to be detected in burned forest than in the next most commonly occupied vegetation type, and all other vegetation types are underused in relation to what is expected on the basis of habitat availability. Only six of 194 woodpecker detections occurred in something other than a burned forest. Within burned forests, the probability of detecting a Black-backed Woodpecker did not differ significantly $\left(\chi^{2}=3.99, \mathrm{df}=5, P=0.55\right)$ among the six major forest types that occur across a broad elevation gradient in Montana (Fig. 3a). This bird species was also relatively restricted in its distribution $\left(\chi^{2}=36.07, \mathrm{df}=3, P<0.0001\right)$ to the severely burned end of the fire severity spectrum (Fig. 3b).

These patterns of Black-backed Woodpecker occurrence among vegetation types and among fire severity categories are unlikely to be artifacts of differences in bird detectability among vegetation or fire severity categories because I minimized the effects of habitat on detectability by using only those point-count data obtained from within a $100 \mathrm{~m}$ radius from the observer. In addition, I used data from an additional 3067 playback experiments conducted across the full range of fire severities from green-tree to blackened forests and discovered the same basic pattern as that generated from fixed-radius point-count data: Black-backed Woodpeckers are nearly absent from unburned forests, and they occur with increasing likelihood as either proximity to fire or fire severity increases $\left(\chi^{2}=132.40\right.$, df $=4, P<$ 0.0001; Fig. 3c).

The probability of detecting a Black-backed Woodpecker also decreased incrementally with intensity of both recent pre-fire $\left(\chi^{2}=31.5, \mathrm{df}=2, P<0.0001\right)$ and recent postfire $\left(\chi^{2}=5.49\right.$, df $\left.=2, P=0.06\right)$ timber harvesting (Fig. 4).

\section{DisCUSSION}

Because $96 \%$ of all Black-backed Woodpecker detections were in burned forest conditions, and because the distribution of playback detections reflects well the distribution of point-count detections, I am confident that the species is relatively restricted to burned forest conditions. Nevertheless, the pattern of occurrence might not reflect the pattern of habitat suitability: a possibility that Van Horne (1983) highlighted more than two decades ago. A mismatch between density (frequency of occurrence) and suitability is perhaps most likely when animals use unnatural, human-altered habitats. It is in those situations that humans run the greatest risk of creating an ecological trap: an attractive habitat that is otherwise relatively unsuitable (Robertson and Hutto 2006). Under naturally occurring conditions, however, it is unlikely that a place where an organism is 16 times more likely to occur than anywhere else is of relatively 
low quality. It is this, combined with knowledge that the reproductive success of black-backed woodpeckers is uniformly high in burned forests (Saab and Dudley 1998, Saab et al. 2007, Vierling et al. 2008), that leads me to believe that burned forests are important to these birds. Thus, the extremely restricted distribution pattern of the Black-backed Woodpecker suggests that conditions created by severe fires probably represent the historical backdrop against which this species evolved.

The implications of this distribution pattern are profound. For one, such a pattern illustrates that severe fire is not only natural, but may also be a necessary part of a wide range of forest ecosystem types in the Intermountain West and beyond. But in which forest types is severe fire well within the natural range of variation? The relatively high and statistically indistinguishable probabilities of detection among a wide range of burned forest types (Fig. 3a) would seem to suggest that severe fires occur naturally across a broad range of forest types and conditions, but it would be risky to draw such an inference from distribution data alone. In fact, the woodpecker species is basically a boreal bird, which suggests that the historically important forest types were probably the higher-latitude and higherelevation forest types. The Black-backed Woodpecker may use severely burned, low-elevation forests entirely opportunistically nowadays as an "unnatural" consequence of the fact that fires are now burning at unnaturally high severity, but it is noteworthy that its probability of occurrence is no different among forest types. To believe that only one or a few forest types burned severely in the past, and that the other forest types are today occupied only opportunistically would require a convergence of all factors necessary not only for woodpecker presence, but for a high level of nest success as well. I find it much more likely that severe fires were important components in all the forest types now occupied by the woodpeckers. The unknowns surround the historical frequency and spatial extent of such fires in each forest type. I believe the lesson best drawn from the data presented here is that perhaps we need to think more seriously about what the natural role of severe fire might have been in low- as well as highelevation forests. The woodpecker distribution patterns are certainly consistent with the idea that some level of severe fire is a natural (even if rare) occurrence in even the lowest elevation forests. This conclusion would be consistent with the conclusions of several recent studies showing that some of the low-elevation ponderosa pine systems are perhaps better characterized by mixedseverity than by low-severity fire regimes (Agee 1993, Shinneman and Baker 1997, Brown et al. 1999, Veblen 2000, Schoennagel et al. 2004, Baker et al. 2007, Hessburg et al. 2007). Thus, statements claiming that severe fire in "western" forests is unprecedented and unnatural may be overly broad; they certainly do not apply to most conifer forests in the northern Rockies (Schoennagel et al. 2004, Noss et al. 2006).
While it may be wise to focus considerable attention on restoration projects designed to prevent severe fire in that subset of forest types where such restoration seems appropriate (e.g., in the dry, low-elevation ponderosa pine forest types, as discussed by Covington and Moore [1994]), the findings here underscore the fact that we must also communicate to the public the equally important need to manage for the creation and retention of severely burned forest conditions across an even larger portion of the forested western landscape. The desire to rid our forests of severe fire beyond the urban interface is, for many forest types, not well grounded in ecological science. Plant ecologists have long known that severe, stand-replacement fires are characteristic of certain forest types (Brown and Smith 2000), but the presence and importance of severe fire in the low- to mid-elevation conifer forest types has not been widely accepted. Results here indicate that severe fire is an important component in most all western conifer forest systems; what varies from system to system are the proportions of the different categories of fire severity distributed across space and time. This is precisely what Agee (1993:24) illustrated so elegantly in his book: all fire severities are associated with low-, moderate-, and high-severity fire regimes; it is the proportion of those fire types that varies across regimes. Once the public begins to accept the importance of keeping some severe fire on the landscape (even in forest types dominated low-severity fire regimes), we can move toward the next challenge: to better understand how much and in what spatial pattern severe fires occurred historically in any given forest type.

The importance of severely burned forest conditions to the black-backed woodpecker carries another important implication related to both pre-fire restoration and postfire logging projects. Pre-fire restoration projects designed to reduce fuels may reduce fire severity under average weather conditions, but are unlikely to prevent severe fires altogether because most severe fires burn under extreme conditions (Gedalof et al. 2005, Schoennagel et al. 2005, 2007, Collins et al. 2006, Westerling et al. 2006). Thus, one might be tempted to believe that burned forest conditions will always be ample for fire specialists, no matter what we do. There are two reasons why this may not be true. First, the legacy (Franklin et al. 2000) of forest structure (e.g., tree sizes and densities) prior to fire disturbance affects the suitability to fire specialists after disturbance. Black-backed Woodpeckers, for example, require burned forests that are densely stocked and have an abundance of large, thick-barked trees favored by wood-boring beetles (Hutto 1995, Saab and Dudley 1998, Saab et al. 2002, Russell et al. 2007, Vierling et al. 2008). Indeed, data collected from within a wide variety of burned forest types show that the probability of Black-backed Woodpecker occurrence decreases dramatically and incrementally as the intensity of traditional harvest methods increases (Fig. 4). Whether forests that have been "restored" through 
nontraditional harvest methods still retain the characteristics needed by Black-backed Woodpeckers after they burn severely under extreme weather conditions is currently unknown.

The second reason why we cannot assume that suitable postfire habitat will always be ample is that, even though severely burned forests will always be plentiful, postfire logging (a common postfire management practice) also reduces the suitability of burned forests to fire specialists like the Black-backed Woodpecker (Kotliar et al. 2002, Hutto 2006, Hutto and Gallo 2006, Koivula and Schmiegelow 2007, Saab et al. 2007). The subset of forest stands routinely slated for salvage sales are nonrandom and probably overlap broadly with stands that are relatively suitable for Black-backed Woodpeckers (Russell et al. 2007) and other firedependent species.

Given the findings here, the challenge for western land managers is one of preventing severe fires from occurring in places where there is imminent danger to human property and lives, while at the same time allowing some severe fires to burn in areas removed from such danger. The latter requires that we value burned forest stands for the biological as well as the economic resources they might provide. As a start, perhaps Smokey the Bear should give up his current blanket statement that "wildfires are bad fires" (statement available online), ${ }^{3}$ and begin to impart the knowledge that severe wildfires are, in most forest systems and in many ways, good fires. Severe wildfires are not "catastrophic" events when they occur in locations beyond where human lives and property are at risk; for most forest types, they are more accurately viewed as naturally occurring disturbance events upon which many plant (Brown and Smith 2000) and animal (Smith 2000) species depend.

\section{ACKNOWLEDGMENTS}

I thank Amy Cilimburg, Ken Dial, Jon Keeley, Tom Martin, Sue Reel, Tom Swetnam, and anonymous reviewers for comments on the manuscript, and the numerous field technicians who helped collect data associated with the Northern Region Landbird Monitoring Program and with my fire research. The land bird monitoring work has been supported by grants or other support provided by the U.S. Forest Service Northern Region, U.S. Department of Interior Bureau of Land Management, Plum Creek Timber Company, Potlatch Corporation, Montana Fish, Wildlife and Parks, and the SalishKootenai Tribes. My fire research has been supported by the National Geographic Society, Glacier National Park, U.S, Forest Service Rocky Mountain Research Station, and Joint Fire Science Program.

\section{Literature Cited}

Agee, J. K. 1993. Fire ecology of Pacific Northwest forests. Island Press, Covelo, California, USA.

Allen, C. D., M. Savage, D. A. Falk, K. F. Suckling, T. W. Swetnam, T. Schulke, P. B. Stacey, P. Morgan, M. Hoffman, and J. T. Klingel. 2002. Ecological restoration of southwest-

${ }^{3}\langle$ http://www.smokeybear.com/good-bad.asp $\rangle$ ern ponderosa pine ecosystems: a broad perspective. Ecological Applications 12:1418-1433.

Arno, S. F., and S. Allison-Bunnell. 2002. Flames in our forest. Island Press, Washington, D.C., USA.

Arno, S. F., and C. E. Fiedler. 2005. Mimicking nature's fire: restoring fire-prone forests in the West. Island Press, Washington, D.C., USA.

Baker, W. L., T. T. Veblen, and R. L. Sherriff. 2007. Fire, fuels and restoration of ponderosa pine-Douglas fir forests in the Rocky Mountains, USA. Journal of Biogeography 34: 251-269.

Barker, F. K., A. Cibois, P. Schikler, J. Feinstein, and J. Cracraft. 2004. Phylogeny and diversification of the largest avian radiation. Proceedings of the National Academy of Sciences (USA) 101:11040-11045.

Brown, J. K., and J. K. Smith. 2000. Wildland fire in ecosystems: effects of fire on flora. General Technical Report RMRS-GTR-42. Volume 2. USDA Forest Service, Ogden, Utah, USA.

Brown, P. M., M. R. Kaufmann, and W. D. Shepperd. 1999. Long-term, landscape patterns of past fire events in a montane ponderosa pine forest of central Colorado. Landscape Ecology 14:513-532.

Collins, B. M., P. N. Omi, and P. L. Chapman. 2006. Regional relationships between climate and wildfire-burned area in the Interior West, USA. Canadian Journal of Forest Research 36:699-709.

Covington, W. W. 2000. Helping western forests heal: the prognosis is poor for US forest ecosystems. Nature 408: 135-136.

Covington, W. W., and M. M. Moore. 1994. Southwestern ponderosa pine forest structure: changes since Euro-American settlement. Journal of Forestry 92:39-47.

Dixon, R. D., and V. A. Saab. 2000. Black-backed Woodpecker (Picoides arcticus). Pages 1-20 in A. Poole and F. Gill, editors. Birds of North America. Birds of North America, Inc., Philadelphia, Pennsylvania, USA.

Donovan, G. H., and T. C. Brown. 2007. Be careful what you wish for: the legacy of Smokey Bear. Frontiers in Ecology and the Environment 5:73-79.

Franklin, J. F., D. Lindenmayer, J. A. MacMahon, A. McKee, J. Magnuson, D. A. Perry, R. Waide, and D. Foster. 2000. Threads of continuity. Conservation Biology in Practice 1: $8-16$.

Gedalof, Z., D. L. Peterson, and N. J. Mantua. 2005. Atmospheric, climatic, and ecological controls on extreme wildfire years in the northwestern United States. Ecological Applications 15:154-174.

Hessburg, P. F., K. M. Reynolds, R. E. Keane, K. M. James, and R. Salter. 2007. Re-examining fire severity relations in pre-management era mixed conifer forests: inferences from landscape patterns of forest structure. Landscape Ecology 22: 5-24.

Hutto, R. L. 1995. The composition of bird communities following stand-replacement fires in northern Rocky Mountain (U.S.A.) conifer forests. Conservation Biology 9:10411058.

Hutto, R. L. 2006. Toward meaningful snag-management guidelines for postfire salvage logging in North American conifer forests. Conservation Biology 20:984-993.

Hutto, R. L., and S. M. Gallo. 2006. The effects of postfire salvage logging on cavity-nesting birds. Condor 108:817-831.

Hutto, R. L., and J. S. Young. 1999. Habitat relationships of landbirds in the Northern Region, USDA Forest Service. USDA Forest Service General Technical Report RMRSGTR- 32:1-72.

Hutto, R. L., and J. S. Young. 2002. Regional landbird monitoring: perspectives from the northern Rocky Mountains. Wildlife Society Bulletin 30:738-750.

Johnson, E. A., K. Miyanishi, and S. R. J. Bridge. 2001. Wildfire regime in the boreal forest and the idea of

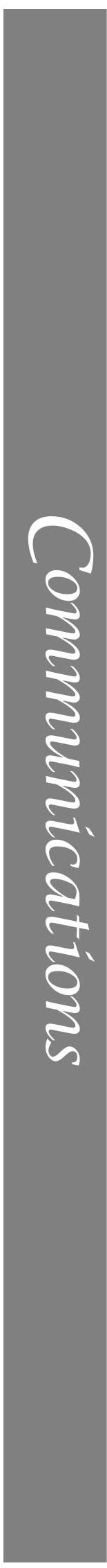


suppression and fuel buildup. Conservation Biology 15:1554 1557.

Koivula, M. J., and F. K. A. Schmiegelow. 2007. Boreal woodpecker assemblages in recently burned forested landscapes in Alberta, Canada: effects of post-fire harvesting and burn severity. Forest Ecology and Management 242:606-618.

Kotliar, N. B., S. J. Hejl, R. L. Hutto, V. A. Saab, C. P Melcher, and M. E. McFadzen. 2002. Effects of fire and postfire salvage logging on avian communities in coniferdominated forests of the western United States. Studies in Avian Biology 25:49-64.

Lutes, D. C., R. E. Keane, J. F. Caratti, C. H. Key, N. C. Benson, and S. Sutherland. 2006. FIREMON: fire effects monitoring and inventory system. General Technical Report RMRS-GTR-164-CD. U.S. Department of Agriculture Forest Service, Rocky Mountain Research Station, Fort Collins, Colorado, USA.

Manly, B. F. J., L. L. McDonald, D. L. Thomas, T. L. McDonald, and W. Erickson. 2002. Resource selection by animals: statistical design and analysis for field studies. Second edition. Kluwer Press, New York, New York, USA.

Noss, R. F., J. F. Franklin, W. L. Baker, T. Schoennagel, and P. B. Moyle. 2006. Managing fire-prone forests in the western United States. Frontiers in Ecology and the Environment 9: 481-487.

Ralph, C. J., J. R. Sauer, and S. Droege. 1995. Monitoring bird populations by point counts. General Technical Report PSW-GTR-149. USDA Forest Service, Pacific Southwest Research Station, Albany, California, USA.

Robertson, B. A., and R. L. Hutto. 2006. A framework for understanding ecological traps and an evaluation of existing ecological evidence. Ecology 87:1075-1085.

Russell, R. E., V. A. Saab, and J. G. Dudley. 2007. Habitatsuitability models for cavity-nesting birds in a postfire landscape. Journal of Wildlife Management 71:2600-2611.

Saab, V., R. Brannon, J. Dudley, L. Donohoo, D. Vanderzanden, V. Johnson, and H. Lachowski. 2002. Selection of firecreated snags at two spatial scales by cavity-nesting birds. General Technical Report PSW-GTR-181. USDA Forest Service, Pacific Southwest Research Station, Albany, California, USA.

Saab, V. A., and J. G. Dudley. 1998. Responses of cavitynesting birds to stand-replacement fire and salvage logging in ponderosa pine/Douglas-fir forests of southwestern Idaho. Research Paper RMRS-RP-11. USDA Forest Service, Rocky Mountain Research Station, Ogden, Utah, USA.

Saab, V. A., R. E. Russell, and J. Dudley. 2007. Nest densities of cavity-nesting birds in relation to post-fire salvage logging and time since wildfire. Condor 109:97-108.

Schoennagel, T., T. T. Veblen, D. Kulakowski, and A. Holz. 2007. Multidecadal climate variability and climate interactions affect subalpine fire occurrence, western Colorado (USA). Ecology 88:2891-2902.

Schoennagel, T., T. T. Veblen, and W. H. Romme. 2004. The interaction of fire, fuels, and climate across Rocky Mountain forests. BioScience 54:661-676.

Schoennagel, T., T. T. Veblen, W. H. Romme, J. S. Sibold, and E. R. Cook. 2005. ENSO and PDO variability affect drought-induced fire occurrence in Rocky Mountain subalpine forests. Ecological Applications 15:2000-2014.

Schwind, B. (compiler). 2008. Monitoring trends in burn severity: report on the Pacific Northwest and Southwest mapped fires. 〈http://www.mtbs.gov〉

Shinneman, D. J., and W. L. Baker. 1997. Nonequilibrium dynamics between catastrophic disturbances and old-growth forests in ponderosa pine landscapes of the Black Hills. Conservation Biology 11:1276-1288.

Smith, J. K. 2000. Wildland fire in ecosystems: effects of fire on fauna. General Technical Report RMRS-GTR-42. Volume 1. USDA Forest Service, Ogden, Utah, USA.

Sokal, R. R., and F. J. Rohlf. 1995. Biometry. Third edition. W.H. Freeman, New York, New York, USA.

Van Horne, B. 1983. Density as a misleading indicator of habitat quality. Journal of Wildlife Management 47:893-901.

Veblen, T. T. 2000. Disturbance patterns in southern Rocky Mountain forests. Pages 31-54 in R. L. Knight, F. W. Smith, S. W. Buskirk, W. H. Romme, and W. L. Baker, editors. Forest fragmentation in the southern Rocky Mountains. University Press of Colorado, Boulder, Colorado, USA.

Vierling, K. T., L. B. Lentile, and N. Nielsen-Pincus. 2008. Preburn characteristics and woodpecker use of burned coniferous forests. Journal of Wildlife Management 72: $422-427$.

Westerling, A. L., H. G. Hidalgo, D. R. Cayan, and T. W. Swetnam. 2006. Warming and earlier spring increases western U.S. forest wildfire activity. Science 313:940-943. 